\title{
Field evaluation of two entomopathogenic fungi; Beauveria bassiana and Metarhizium anisopliae as a biocontrol agent against the spiny bollworm, Earias insulana Boisduval (Lepidoptera: Noctuidae) on cotton plants
}

\author{
Dalia El Sayed Lotfy and Hemat Zakaria Moustafa*
}

\begin{abstract}
Background: The Earias spp. are devastating pests which reduce cotton yield up to $40 \%$ as seed cotton. Efficacy of Metarhizium anisopliae and Beauveria bassiana as bio-insecticides were investigated against the spiny bollworm, Earias insulana Boisduval (Lepidoptera: Noctuidae), under field conditions in Egypt throughout two successive seasons 2018 and 2019.

Results: Results showed E. insulana population reduction during both seasons after bio-insecticidal applications. $M$. anisopliae strains $(\mathrm{S} 1, \mathrm{~S} 2)$ treatments showed significant reductions in the mean numbers of infested bolls with $E$. insulana after 14 days from the 1st spray. Reduction percentages of E. insulana infestation reached to 77.74 and $76.51 \%$ respectively, after application of $M$. anisopliae strains (S1, S2) treatments; then, the infestation reduction percentages increased to 88.48 and $85.41 \%$ after the 2nd spray by the same fungal strains; then, the infestation reduction percentages increased to 90.16 and $90.84 \%$ after 3rd spray of the same fungal strains in season 2018. In 2019 season, the infestation reduction percentages of E. insulana was 85.48 and $80.75 \%$, after the 1 st spray of $M$. anisopliae strains (S1, S2), respectively, which increased to 92.40 and $89.87 \%$, after 14 days from the 2nd spray by the two fungal strains respectively, and then increased to 94.12 and $93.73 \%$, after 14 days from the 3rd spray of $M$. anisopliae (S1 and S2) respectively. In season 2018, the infestation reduction percentage of E. insulana by B. bassiana strains (S1, S2) recorded 73.09 and 71.89\%, respectively and 81.04 and 82.89\% respectively, in season 2019, after 14 days of the 1st spray. While after the 2 nd spray of the two tested B. bassiana strains, the infestation reduction percentage of E. insulana was 85.41 and $85.41 \%$ respectively, in season 2018 , whereas it was 89.16 and $89.16 \%$ respectively, in season 2019. Then after 14 days of the 3rd spray by the same fungus strains, the reduction percentage of E. insulana increased to 86.56 and $85.35 \%$, respectively, in season 2018 , and 90.83 and $90.83 \%$ in season 2019.
\end{abstract}

Conclusions: Tested strains of B. bassiana and M. anisopliae fungi proved their potential for decreasing E. insulana infestation percentages through 2-3 spray treatments under field conditions.

Keywords: Earias insulana, Biopesticides, Metarhizium anisopliae, Beauveria bassiana, Field application, Cotton

*Correspondence: hemat.zakaria@gmail.com

Plant Protection Research Institute, Agriculture Research Center, Dokki, Giza,

Egypt

SpringerOpen

(c) The Author(s). 2021 Open Access This article is licensed under a Creative Commons Attribution 4.0 International License, which permits use, sharing, adaptation, distribution and reproduction in any medium or format, as long as you give appropriate credit to the original author(s) and the source, provide a link to the Creative Commons licence, and indicate if changes were made. The images or other third party material in this article are included in the article's Creative Commons licence, unless indicated otherwise in a credit line to the material. If material is not included in the article's Creative Commons licence and your intended use is not permitted by statutory regulation or exceeds the permitted use, you will need to obtain permission directly from the copyright holder. To view a copy of this licence, visit http://creativecommons.org/licenses/by/4.0/. 


\section{Background}

Cotton (Gossypium barbadense) (Malvaceae) is the most important industrial crop worldwide (Johnson et al., 2014). In Egypt, cotton plants like most of the field crops are attacked by many lepidopterous pest species (Gaaboub et al., 2012). Insect pests are the most limiting factors that decrease cotton production and cause severe damages to the crop yield (El-Heneidy et al., 2015). The spiny bollworm, Earias insulana Boisduval (Lepidoptera: Noctuidae), the mid-late season pest, usually threats cotton plants in Egypt (El Hamaky et al., (1990). The damage of fruits (green bolls) is frequently more destruction than the other parts of the cotton plant. E. insulana and the pink bollworm, Pectinophora gossypiella (Saund.) (Lepidoptera: Gelechiidae), are the most destructive insect pests of cotton in Egypt (Amin and Gergis, 2006). Biopesticides based on bacteria, viruses, entomopathogenic fungi, and nematodes are often considerable scope as a plant protection agent against several insects. Many works extensively investigated the field bio-efficacy of the entomopathogenic fungi (EPF) such as Beauveria bassiana (Balsamo) Vuillemin (Deuteromycotina: Hyphomycetes) (Wraight et al., 2010).

The present study aimed to evaluate the potential of $\mathrm{EPF}$, as bio-insecticides against the spiny bollworm, $E$. insulana, under field conditions.

The present study aimed to evaluate the potential of $E P F$, as bio-insecticides against the spiny bollworm, $E$. insulana under field conditions.

\section{Methods}

\section{Fungi culture sources}

Two tested fungi, Beauveria bassiana and Metarhizium anisopliae, were obtained from 2 sources: the first (S1), isolate of B. bassiana (Balsamo) AUMC NO (5133) and $M$. anisopliae (Metschnikoff) Sorokin AUMC NO (5130), obtained from the Assiut University, Mycological Center Faculty of Science, Egypt. The second source (S2) was the wettable powder of the commercial bioagents Bioranza ${ }^{\circ}$ WP 10\% (M. anisopliae Sorok.). Active ingredients $10 \%$, Inert Ingredient $90 \%$, formulated as a wettable powder with the count of $1 \times 10^{8}$ spore $/ \mathrm{ml}$ and Biovar WP 10\% (B. bassiana Balsamo) active ingredients $10 \%$, Inert Ingredient $90 \%$, formulated as a wettable powder with the count of $1 \times 10^{8}$ spore $/ \mathrm{ml}$.

\section{Preparation of specific media}

The isolates were cultured on Sabouraud dextrose agar medium $\mathrm{g} / \mathrm{l}$ containing $40 \mathrm{~g}$ glucose, $20 \mathrm{~g}$ peptone, $20 \mathrm{~g}$ agar, $2 \mathrm{gm}$ yeast extract, and $1000 \mathrm{ml}$ of distilled water in flasks. These flasks were autoclaved at $21^{\circ} \mathrm{C}$ for $15 \mathrm{~min}$.

\section{Preparation of tested bioagent}

The two sources were prepared as solutions as follows:
Source 1 (S1): Fungal cultures were grown on Sabouraud dextrose agar medium (Dextrose 40gm, agar 20gr, peptone $10 \mathrm{~g}) / 1000 \mathrm{ml}$ distilled water and incubated at $25 \pm 2{ }^{\circ} \mathrm{C}$ in darkness for 14 days. Conidial suspensions were prepared by scraping cultures with a sterile objective glass and transferred to $10 \mathrm{ml}$ of sterile water containing $0.05 \%$ Tween 80 in a laminar flow chamber. The mixture was stirred for 10 min the hyphal debris was removed by filtering the mixture through fine mesh sieve. The conidial concentration of final suspension was determined by direct count $1 \times 10^{8}$ using hemocytometer with final concentration of $1 \times 10^{8}$ spore $/ \mathrm{ml}$.

Source 2 (S2): To prepare stock solution $\left(1 \times 10^{8}\right)$, spore $/ \mathrm{ml}$ from the commercial bioagent was weighted, 5 gram of powder, and dissolved in $900 \mathrm{ml}$ sterile water.

\section{Field application}

Field study was conducted at Talaat-El Agamy experimental farm, henno, Kafr El-Sheikh, Egypt. Studies covered two successive cotton growing seasons 2018 and 2019. Cotton variety Giza 96 was cultivated on April 7, 2018, and on April 13, 2019 seasons. The experimental design was complete randomized block, the whole cultivated area $\left(350 \mathrm{~m}^{2}\right)$ was divided into equally 5 plots each was divided to 3 replicates, each plot was treated by one of the tested 4 bioinsecticides strain individually with a concentration of $1 \times 10^{8} \mathrm{spore} / \mathrm{ml} / \mathrm{l}$ water. The last plot was left untreated as control. Cotton seeds were sown at $20-\mathrm{cm}$ distance between hills. Two sources of the 2 EPF were applied against E. insulana on infested cotton green bolls when infestation reached 3\% (the economic threshold). Spraying of the tested fungi took place on cotton plants 3 times on July, 8th, 22nd and 5th August, respectively through the 2 seasons. Fungal applications were carried out at $4 \mathrm{pm}$ using a knapsack motor sprayer (20-1 capacity). To evaluate the effect of the 4 EPF strains against E. insulana, samples of 25 bolls/plot were picked randomly before and 1 week after applications. Sampling continued weekly until harvest. The collected bolls were carefully dissected, and the numbers of larvae, infested bolls, and reduction percentages were recorded. The reduction percentages in the field experiment were calculated.

\section{Statistical analysis}

Data of E. insulana infestation after 7 and 14 days of treatments were statistically analyzed by one-way analysis of variance (ANOVA) $(P<0.05 \%)$ Duncan's multiple range test of means (Duncan, 1955). The reduction percentages of $E$. insulana at different application time 
interval were calculated according to Henderson and Tilton (1955):

$=1-\frac{(\text { No.in control before treatment } \times \text { No.in treatment after treatment })}{(\text { No.in control after treatment } \times \text { No.in treatment before treatment })} \times 100$

\section{Results \\ Effect of the tested entomopathogenic fungi on $E$. insulana under field conditions}

In the control plot, larval population increased gradually throughout all the inspection weeks in the 2 studied growing seasons (Tables 1 and 2).

Data in Table 1 showed that applications of M. anisopliae (S1, S2) treatments significantly reduced the mean numbers of infested bolls with $E$. insulana after 7 days post the 1st spray with the reduction percentages of 60.69 and $51.74 \%$, respectively, while 77.74 and $76.51 \%$ after 14 days from the 1 st spray the reduction percentages increased to 88.37 and $61.89 \%, 7$ days from the 2 nd spray. The reduction \% by $M$. anisopliae (S1, S2) applications attained 88.48 and $85.63 \%$, respectively, after 14 days from the 2nd spray. Afterward, the percentages of infestation reduction reached 92.5 and $90.16 \%$ after 7 days from the 3rd spray: 90.13 and $90.84 \%$ after 14 days from the 3rd spray in season 2018.

The reduction percentage of E. insulana in case of B. bassiana (S1, S2) in season 2018 recorded 54.61 and $49.24 \%$, respectively, after 7 days from the 1 st spray, and 73.09 and $71.89 \%$, respectively, after 14 days, while it was 85.09 and $83.57 \%$, respectively, after 7 days from the 2 nd spray, and 85.41 and $85.41 \%$, respectively, after 14 days from the 2nd spray; then, the reduction percentage increased to 89.00 and $88.12 \%$, respectively, after 7 days from the 3 rd spray, and 86.56 and $85.35 \%$, respectively, after 14 days from the 3rd spray.

Results in Table 2 clarified that application of $M$. anisopliae (S1, S2) treatments showed significant reductions in the mean numbers of infested bolls with E. insulana than the control after 7 days from the 1st spray in season 2019 and these percentages reached to 79.54 and $72.72 \%$, respectively, and then increased to 85.48 and $80.75 \%$, respectively, after 14 days from the 1st spray, whereas, the reduction percentages were 91.02 and $87.59 \%$, respectively, after 7 days from the 2nd spray, and they were 92.40 and $89.87 \%$, respectively, after 14 days from the 2 nd spray of $M$. anisopliae (S1, S2) treatments in season 2019. Afterward, the reduction percentages of $E$. insulana Infestation increased to 95.42 and $95.12 \%$, respectively, after 7 days from $M$. anisopliae (S1, S2) spray, and reached to 94.12 and $93.73 \%, 14$ days from the 3rd spray.
Also, Table 2 shows the reduction percentages of $E$. insulana by the 1st application of B. bassiana (S1, S2) (70.61 and 74.69\%, respectively), after 7 days and (81.04 and $82.89 \%$, respectively) after 14 days of treatments. While for the 2nd spray of B. bassiana (S1, S2) treatments, the reduction percentages of $E$. insulana were 86.48 and $88.42 \%$, respectively, after 7 days whereas they were 89.16 and $89.16 \%$, respectively, after 14 days from treatments. Then, the reduction percentages of $E$. insulana increased to 92.93 and $92.78 \%$, respectively, after 7 days from the $3^{\text {rd }}$ spray of $B$. bassiana (S1, S2) whereas they were 90.83 and $90.83 \%$, respectively, after 14 days from the 3rd spray by the same strains, during season 2019.

Data in Table 3 shows that there were significant differences between means of infestations after 7 and 14 days treatments when the $\mathrm{p}$-value is $<0.05$ ).

\section{Discussion}

Obtained results showed that both $M$. anisopliae and $B$. bassiana strains were elicited effects toward $E$. insulana under field experiment. M. anisopliae (S1, S2) showed the best effect toward E. insulana infestation reduction percentage after 3 sprays of each treatments, under field conditions followed by $B$. bassiana S1, S2. In this respect, Abd-ElAzeem et al. (2019) investigated the biological activities of spores and metabolites of some fungi against the newly hatched larvae of E. insulana. Results showed that the fungi $M$. anisopliae had more effectiveness to the newly hatched larvae. Also, spore suspensions of the all fungal isolates had the highest larval mortality than fungal metabolites. Moustafa et al. (2019) found that toxicity of $M$. anisopliae was high in case of $E$. insulana treatment. Dar et al. (2020) reported that $M$. anisopliae and B. bassiana either isolates or (W.P.) with Economy Micron ULVA (15 L./Fed.) were the most effective applications in reduction percentage of boll infestation with E. insulana followed by Bacillus thuringiensis, whereas, Hegab and Zaki (2012) found that B. bassiana gave a low larval mortality against $E$. insulana.

\section{Conclusion}

It could be concluded that B. bassiana and $M$. anisopliae proved to be efficient EPF against E. insulana. These fungi induced significant reductions for the mean numbers of infested bolls with the pest. $B$. bassiana and $M$. anisopliae are commonly used as pathogens against many insect species. Generally, the tested strains can be suggested as promising fungi to be used in biological control program of E. insulana in the field application. 


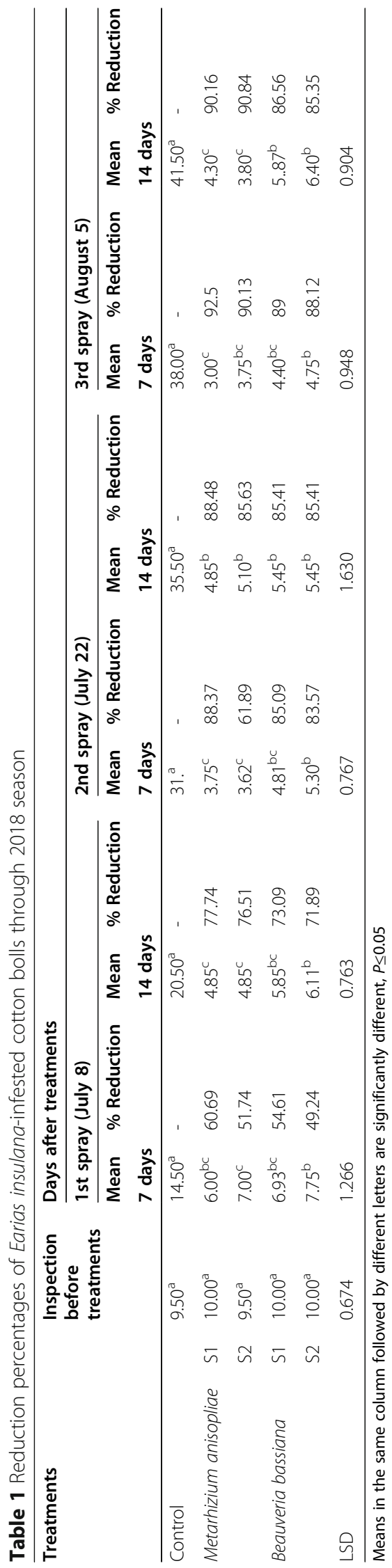




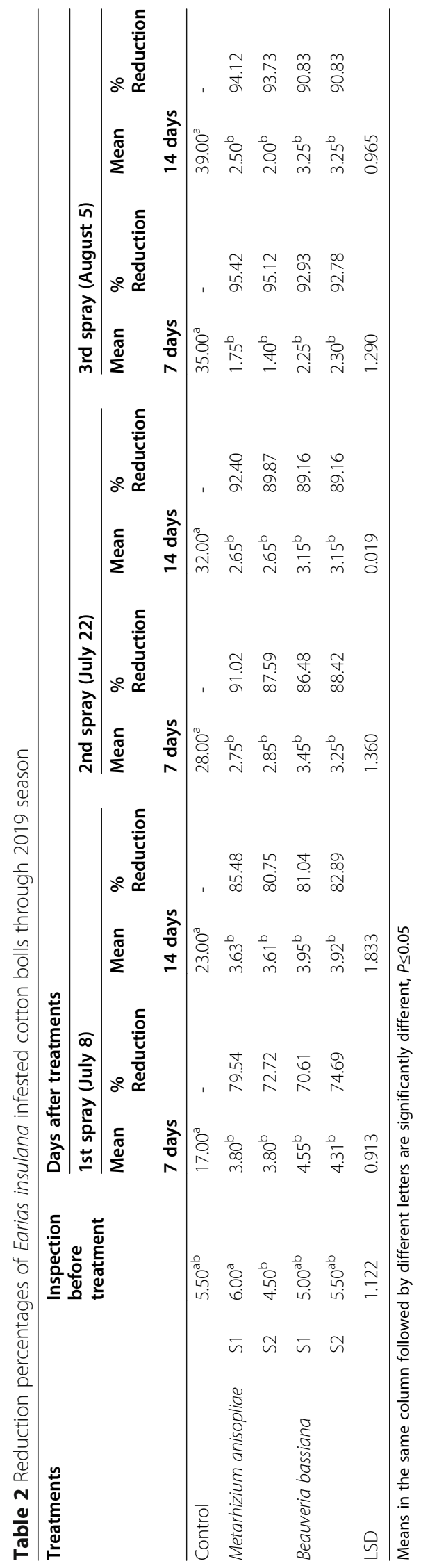


Table 3 T-test comparison between the mean infestations of Earias insulana after using the two fungal after 7 and 14 days at each treatment and control in 2018 and 2019 seasons

\begin{tabular}{|c|c|c|c|c|c|c|c|c|c|c|c|c|c|}
\hline \multirow[t]{4}{*}{ Treatment } & & \multicolumn{6}{|c|}{ Days after treatments of season 2018} & \multicolumn{6}{|c|}{ Days after treatments of season 2019} \\
\hline & & \multirow{2}{*}{\multicolumn{2}{|c|}{$\begin{array}{l}\text { 1st spray (July } \\
\text { 8) } \\
\text { Mean }\end{array}$}} & \multirow{2}{*}{\multicolumn{2}{|c|}{$\begin{array}{l}\text { 2nd spray (July } \\
\text { 22) } \\
\text { Mean }\end{array}$}} & \multirow{2}{*}{\multicolumn{2}{|c|}{$\begin{array}{l}\text { 3rd spray (August } \\
\text { 5) } \\
\text { Mean }\end{array}$}} & \multirow{2}{*}{\multicolumn{2}{|c|}{$\begin{array}{l}\text { 1st spray (July } \\
\text { 8) } \\
\text { Mean }\end{array}$}} & \multirow{2}{*}{\multicolumn{2}{|c|}{$\begin{array}{l}\text { 2nd spray (July } \\
\text { 22) } \\
\text { Mean }\end{array}$}} & \multirow{2}{*}{\multicolumn{2}{|c|}{$\begin{array}{l}\text { 3rd spray (August } \\
\text { 5) } \\
\text { Mean }\end{array}$}} \\
\hline & & & & & & & & & & & & & \\
\hline & & 7 days & 14 days & 7 days & 14 days & 7 days & 14 days & 7 days & 14 days & 7 days & 14 days & 7 days & 14 days \\
\hline Control & & * & & NS & & NS & & * & & NS & & NS & \\
\hline \multirow[t]{2}{*}{ Metarhizium anisopliae } & S1 & NS & & NS & & NS & & NS & & NS & & NS & \\
\hline & S2 & NS & & NS & & NS & & NS & & NS & & NS & \\
\hline \multirow[t]{2}{*}{ Beauveria bassiana } & S1 & NS & & NS & & NS & & NS & & NS & & NS & \\
\hline & S2 & NS & & NS & & NS & & NS & & NS & & NS & \\
\hline
\end{tabular}

*Significant $(\leq 0.05)$, NS not significant

\section{Acknowledgements}

Not applicable

\section{Authors' contributions}

Equally contribution for DEL and HZM. All authors have read and approved the manuscript.

\section{Funding}

Not applicable

\section{Availability of data and materials}

All data in the tables are so clear and these numbers are the raw data.

\section{Declarations}

Ethics approval and consent to participate

Not applicable

\section{Consent for publication}

Not applicable

\section{Competing interests}

The authors declare that they have no competing interests.

Received: 1 December 2020 Accepted: 19 April 2021

Published online: 06 May 2021

\section{References}

Abd-ElAzeem EM, El-Medany WAZ, Sabry HM (2019) Biological activities of spores and metabolites of some fungal isolates on certain aspects of the spiny bollworms Earias insulana (Boisd.) (Lepidoptera: Noctuidae). Egypt J Biol Pest Control 29(90). https://doi.org/10.1186/s41938-019-0192-y

Amin AA, Gergis MF (2006) Integrated management strategies for control of cotton key pests in middle Egypt. Agron Res 4:121-128

Dar RAA, Lotfy DE, Moustafa HZ (2020) Field application of bio-insecticides on spiny bollworm, Earias insulana (Bosid.) On Cotton by using recent low volume ground spraying equipment, Egypt. Acad J Biolog Sci 13(1):47-57

Duncan DB (1955) Multiple range and multiple F test. Biometrics 11(1):1-42. https://doi.org/10.2307/3001478

El Hamaky MA, Moawad GM, Radwan SM, Oman MS (1990) Effect of pheromone mixed with cheated foliar fertilizers of spiny boll worm. Bull Soc Egypt Econ 19(1):113-119

El-Heneidy AH, Khidr AA, Taman AA (2015) Side-effects of insecticides on nontarget organisms: 1- In Egyptian Cotton Fields. Egypt J Biol Pest Control 25(3):685-690. https://doi.org/10.1186/s41938-018-0081-9

Gaaboub IA, Halawaa S, Rabiha A (2012) Toxicity and biological effects of some insecticides, IGRs and Jojoba oil on cotton leafworm Spodoptera littoralis (Boisd.). J Appl Sci Res 2:131-139

Hegab ME, Zaki AA (2012) Toxicological and biological effects of bacteria, Bacillus thuringiensis on Pectinophora gossypiella and entomopathogenic fungi,
Beaveria bassiana on Earias insulana. J Plant Prot Path., Mansoura Univ 3(3): 289-297

Henderson CF, Tilton EW (1955) Tests with acaricides against the brown wheat mite. J Econ Entomol 48(2):157-161. https://doi.org/10.1093/jee/48.2.157

Johnson J, MacDonald S, Meyer L, Norrington B, Skelly C (2014) The world and United States Cotton Outlook. Agricultural Outlook Forum 2014:16. https:// doi.org/10.22004/ag.econ.168329

Moustafa HZ, Lotfy DE, Hassan KA (2019) Effect of entomopathogenic fungi on Pectinophora gossypiella (Lepidoptera: Gelechiidae) and Earias insulana (Lepidoptera: Noctuidae) and their predators. Egypt J Plant Prot Res Inst. 2(1): 9-15

Wraight SP, Ramos ME, Avery PB, Jaronski ST, Vandenberg JD (2010) Comparative virulence of Beauveria bassiana isolates against lepidopteran pests of vegetable crops. J Invertebr Path 103(3):186-199. https://doi.org/10.1016/j. jip.2010.01.001

\section{Publisher's Note}

Springer Nature remains neutral with regard to jurisdictional claims in published maps and institutional affiliations.

\section{Submit your manuscript to a SpringerOpen ${ }^{\circ}$ journal and benefit from:}

- Convenient online submission

- Rigorous peer review

- Open access: articles freely available online

High visibility within the field

- Retaining the copyright to your article

Submit your next manuscript at $\boldsymbol{\nabla}$ springeropen.com 